\title{
The effect of presenting complaint on the risk of developing ventilator-associated pneumonia for patients intubated in an academic emergency department
}

\author{
L DeLuca ${ }^{*}$, T Durns, R Miller, J Yeaton, A Pickering, Z Roward, D Sabb, KR Denninghoff \\ From ESICM LIVES 2015 \\ Berlin, Germany. 3-7 October 2015
}

\section{Introduction}

Ventilator associated pneumonia (VAP) is a complication of mechanical ventilation that increased ICU length of stay and mortality. Eckert found $26 \%$ of trauma patients intubated in the ED develop VAP as compared to $6.5 \%$ of those intubated in the ICU. Green demonstrated that $70 \%$ of critically ill patients were intubated pre-hospital or in the ED and $18.2 \%$ remained in the ED for more than 4 hours.

\section{Objectives}

To identify patients intubated in the ED who are at risk for VAP and characterize the effect of presenting complaint on VAP risk and prevalence.

\section{Methods}

A retrospective study was performed using an existing QI database of patients intubated in the ED. For the purposes of this study. "At-risk for VAP" was defined as intubated $>48$ hours, with no significant abnormality on chest $\mathrm{x}$-ray in the first 48 hours. "At-risk" patients were identified as VAP positive if they had a new persistent infiltrate on
CXR with temperature outside $36^{\circ}-38^{\circ} \mathrm{C}$, and leukocyte count outside 4,000-12,000. Chart review was performed in order to categorize patients by presenting complaints and determine VAP risk and incidence.

\section{Results}

539 patients were included in the ED intubation cohort, of which 244 presented with traumatic complaints. Within the group, 25\% (60) were found to be at risk for VAP and 45\% (27) of these developed VAP. 295 patients had medical presenting complaints. 16\% (47) of medical patients were at risk for VAP and $17 \%$ (8) of these developed VAP. Trauma of unknown or less prevalent mechanism was categorized as Other Trauma, including TBI's and multi trauma. $28 \%$ of this group was at risk for VAP and $79 \%$ of these were VAP positive. $19 \%$ of gunshot wounds were at risk and $67 \%$ developed VAP. Neurology complaints presented with a low occurrence with $24 \%$ at risk and only $10 \%$ of these developing VAP. Cardiac, gastrointestinal and stabbing complaints had no incidences of VAP. Table 1 and 2, as well Figure 1 detail VAP risk and incidence by presenting complaints.

Table 1 Medical Patients VAP Risk and Incidence.

\begin{tabular}{lllllll}
\hline & Respiratory & Neurologic & Cardiac & Psychiatric & Gl & Multisystem / other \\
\hline Total Patients & 59 & 87 & 28 & 57 & 9 & 55 \\
\hline$\%$ at risk for VAP & $9(15 \%)$ & $21(24 \%)$ & $1(4 \%)$ & $6(11 \%)$ & $1(11 \%)$ & $9(16 \%)$ \\
\hline$\%$ at risk who developed VAP & $2(22 \%)$ & $2(10 \%)$ & $0(0 \%)$ & $1(17 \%)$ & $0(0 \%)$ & $3(33 \%)$ \\
\hline
\end{tabular}


Table 2 Trauma Patients VAP Risk and Incidence.

\begin{tabular}{llllll}
\hline & MVA & Falls & GSW & Stabbing & Other Trauma \\
\hline Total Patients & 119 & 30 & 31 & 14 & 50 \\
\hline$\%$ at risk for VAP & $31(26 \%)$ & $8(27 \%)$ & $6(19 \%)$ & $1(7 \%)$ & $14(28 \%)$ \\
\hline at risk who developed VAP & $9(29 \%)$ & $3(38 \%)$ & $4(67 \%)$ & $0(0 \%)$ & $11(79 \%)$ \\
\hline
\end{tabular}

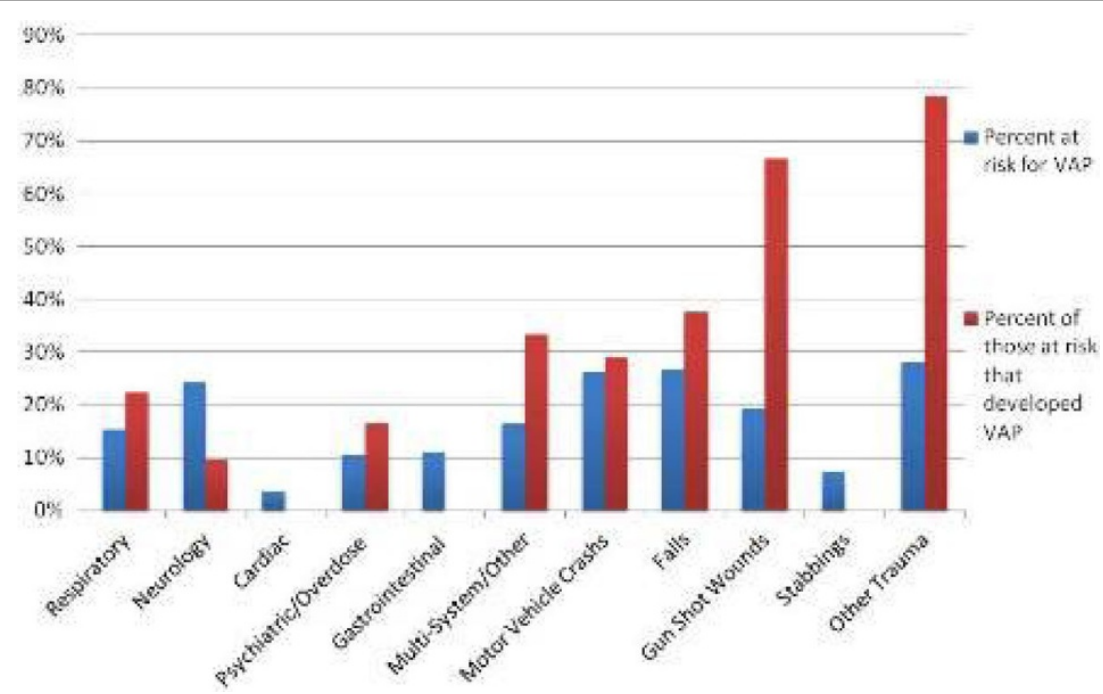

Figure 1 VAP risk and Incidence by Presenting Complaint.

\section{Conclusions}

Patients that arrived to the ED after a traumatic injury were at higher risk for VAP and developed VAP more frequently than those who presented with medical complaints. Future study, including a larger sample, is needed to continue to characterize VAP risk as related to presenting complaint and to determine interventions to reduce this risk.

Published: 1 October 2015

\section{References}

1. Eckert MJ, Davis KA, Reed RL, Santaniello JM, Poulakidas S, Esposito TJ, et al: Ventilator-associated pneumonia, like real estate: location really matters. J Trauma 2006, 60:104-110.

2. Green RS, MacIntyre JK: Critical care in the emergency department: an assessment of the length of stay and invasive procedures performed on critically ill ED patients. Scand I Trauma Resusc Emerg Med 2009, 17:47, Sep 24;(doi):10.1186/757-7241-17-47.

doi:10.1186/2197-425X-3-S1-A99

Cite this article as: DeLuca et al.: The effect of presenting complaint on the risk of developing ventilator-associated pneumonia for patients intubated in an academic emergency department. Intensive Care

Medicine Experimental 2015 3(Suppl 1):A99.

\section{Submit your manuscript to a SpringerOpen ${ }^{\circ}$ journal and benefit from:}

- Convenient online submission

- Rigorous peer review

- Immediate publication on acceptance

- Open access: articles freely available online

- High visibility within the field

- Retaining the copyright to your article

Submit your next manuscript at $>$ springeropen.com 